\title{
Comparison of Formal and Informal Land Administration Systems in Lagos State: The Case of Epe LGA
}

\author{
Chukwuemeka Patrick Ogbu ${ }^{1}$, and Patience Iruobe ${ }^{2}$
}

${ }^{1}$ Department of Quantity Surveying, University of Benin

2 Department of Estate Management, University of Benin

To cite this article: Ogbu, C.P. \& Iruobe, P. (2018). Comparison of Formal and Informal Land Administration Systems in Lagos State: The Case of Epe LGA. Journal of African Real Estate Research, 3(2), pp.18-43. DOI: 10.15641/jarer.v0i0.567.

\begin{abstract}
The efficient harnessing of land resources remains key to unlocking the potential of economies in Sub-Saharan Africa. Land administration systems provide a veritable platform for coordinating the efforts aimed at maximising the overall value of a country's land resources. Extant studies, however, provide scanty and unorganised insight into the problems and benefits of the formal and informal land administration systems co-existing in Nigeria and how they affect physical development on land. Using a cross-sectional survey, this study investigated the benefits and problems of formal and informal land administration systems in Epe, Lagos, and ascertained the relationship between the level of land development and land occupants' type of occupancy (which may be formal or informal). A major problem of the formal land administration system is that to be allocated land; one needs to know a government official, while its key benefit is that anyone can be allocated land anywhere irrespective of their state of origin. Under the informal land administration system, the main problem is that additional "settlement(s)" are required before one can build on the land, while its key benefit is that one purchases land in the place of one's choice. Using logistic regression analysis, it was observed that the level of development of land is independent of the type of occupancy held by the occupant. The study concludes that formal land administration system does not necessarily lead to higher land development than informal land administration. Future land formalisation policies should seek to optimise the merits and minimise the challenges of the two systems of land administration.
\end{abstract}

Keywords: Epe LGA; Lagos State; Land Administration; Land Use Act; Modernisation Theory; Personhood Theory

\footnotetext{
${ }^{1}$ chukwuemeka.ogbu@uniben.edu

2 patienceiruobe@uniben.edu
} 


\section{Introduction}

Globally, a rise in population creates serious land administration problems in the urban space [United Nations Human Settlements Programme (UNHabitat), 2014]. The United Nations (UN) (2014) highlighted that $54 \%$ of the world's population live in urban areas and that this figure is expected to hit $66 \%$ by the year 2050 . At that time (2050), $56 \%$ of Africans are expected to be living in urban areas. Nigeria is among the three countries (others being India and China) expected to lead the world's urban population growth. In Nigeria, Lagos State is generally acknowledged as having the fastest urban population growth (Aina, 1990; Aluko et al., 2004; Ayeni, 2016; Egunjobi \& Adebayo, 2016). Ayeni (2016) estimated that the population of the city increased by $754 \%$ in 55 years between 1960 and 2015. This population growth has placed pressure on existing land administration systems due to the increased quest to obtain different forms of interest on land (Agbola, 2006; Ayeni, 2016).

Naturally, as the crises associated with global urban population growth, namely; overcrowding, high crime rates and poor urban living conditions (Ajanlekoko, 2001), began to manifest, Lagos began to annex neighbouring rural communities and to reclaim unused marshy land. Table 1 shows the expansion of Lagos's landmass over the years. Amongst others, the consequence of this expansion is a conflict of rights over land in the rural areas, which were previously held by traditional communities. There remains a dearth of literature juxtaposing the features of the formal system of land administration, which formed the basis of the expansion, and those of the informal (communal) land administration that existed in the rural communities.

Table 1: Landmass of Lagos at Different Dates

\begin{tabular}{cl}
\hline Date & Landmass of Lagos \\
\cline { 2 - 2 } Up to 1901 & $4 \mathrm{~km}^{2}$ \\
1911 & $15 \mathrm{~km}^{2}$ \\
1920 & $51.8 \mathrm{~km}^{2}$ \\
1927 & $62 \mathrm{~km}^{2}$ \\
1931 & $63 \mathrm{~km}^{2}$ \\
1967 & $70 \mathrm{~km}^{2}$ \\
2016 & $3,577 \mathrm{~km}^{2}$ \\
Source: Adapted from Aina (1990), Njoku (2004) and Oteri and Ayeni (2016)
\end{tabular}

As noted by UN-Habitat (2015), two main theories underlie land administration - the Modernisation Theory which favours state control, commodification and equitable distribution of land, and the Personhood Theory which emphasises communal ownership of land. The former is regarded as formal land administration system, while the latter is regarded as informal land administration system throughout this work. These two systems of land administration coexist in Nigeria (Bah et al., 2003) and have given rise to formal and informal land occupancy types. Aligning with the Modernisation Theory, informal land administration in the annexed rural communities was criticised for limiting development by denying the 
government, and other investors, access to the right environment for creating economic activities. It was argued that under informal land administration, land title documents were either non-existent or unreliable, and lands under the system scarcely attained their economic potentials. In addition, particularly in Lagos State, informal land transactions were reported to be fraught with problems of fraud, especially those created by the "Omo-Oniles" (descendants of the original owners of the land) (Olokoyo et al., 2014; Owoeye \& Adedeji, 2015). The "Omo-Oniles" defraud individuals who want to buy land or obstruct the use of land legitimately purchased from a community by violent means (Nubi \& Ajoku, 2011). Irrespective of this, it is still believed that the informal land administration system is better suited to addressing land and home ownership by the poor (Omirin, 1999). This study, therefore, ascertains the benefits (if any) of the informal land administration system to aid future policy reviews.

The Land Use Act (LUA) 1978 (Chapter L5 Laws of Federation of Nigeria, 2004) was enacted to correct the perceived anomalies of the informal land administration system and create a harmonised formal system of land administration for Nigeria. Thus, more than any other statute, the LUA is the cornerstone of formal land administration in Nigeria because it ceded control over land to the governors of the states. However, the LUA was not a derivative of the land occupants' opinion, rather, it evolved from the Land Use Decree of 1978 which was first adopted as an act of the National Assembly in the 1979 Constitution of the Federal Republic of Nigeria. Ignoring the land occupants' inputs in the legislation process questioned the practical relevance of the LUA. Feedbacks on the impacts of the LUA on the land users is critical to the improvement of the formal land administration system in Nigeria.

Some authors criticise formal land administration for being too bureaucratic, expensive, un-African and time-consuming (Boudreaux, 2008; Toulmin, 2009). Aware of this, Lagos State introduced measures to mitigate the deficiencies through the establishment of the Electronic Document Management System (EDMS), specifying the workflow for title registration processes, reducing the fees payable, and specifying the amounts required in advance (Department for International Development (DFID), 2010). Nubi and Ajoku (2011) further revealed that in 2005, the Lagos State government introduced a 30-day governor's consent policy which sought to reduce the length of time required to obtain a certificate of occupancy $(\mathrm{C}$ of $\mathrm{O})$ or governor's consent. Despite these efforts, it is not generally agreed that formal land administration in Lagos has become satisfactory. For instance, the World Bank (2014) observed the persistence of high transaction costs for obtaining land titles and/or $\mathrm{C}$ of $\mathrm{O}$ with attendant inefficiency in the use of land in Lagos State. Mogbogunje (2005) noted that besides the delays in obtaining a $\mathrm{C}$ of $\mathrm{O}$, landowners were made to repeatedly seek the consent of the governor for every change of land ownership. The above has led to the preference of the informal land market to the formal. This preference, however, was not empirically established, and few recent studies compare the merits and problems of the two (formal and informal) land administration systems in Nigeria. Some authors have given attention to the problems resulting from the implementation of the LUA (Smith, 2008), albeit, without sufficient attempts to carefully identify all the problems associated with the 
law from the land user's perspective, a gap which the current study seeks to fill.

Literature is replete with arguments for and against the formal and informal systems of land ownership and administration in Nigeria. Relying on the Modernisation Theory, those in support of formalisation cite security of tenure, access to land for economic development, equity, land use redistribution, and enshrinement of an open market mechanism as reasons why the system should continue (Njoh, 2000). Furthermore, it has been argued that land formalisation enhances physical development of land (Varley, 1987; Ikejiofor, 2006). Ensminger (1997), however, reported that the benefits of land title formalisation had not materialised irrespective of the adoption of formal land administration in Africa. The veracity of this assertion has gone unchallenged in Nigeria's case. Contrastingly, based predominantly on the Personhood Theory, the informal system of land administration has been commended for being pro-poor, simpler in terms of procedure, and embedded in the existing cultural systems of the society (Rakodi \& Leduka, 2004). Nubi and Ajoku (2011) found that the informal land administration system aided housing production far more than the formal system. Thus, the applicability of either the Modernisation or the Personhood Theory to land administration in Nigeria remains open to conjecture.

Some studies have called for a system that optimises the benefits of the two land administration systems (Migot-Adholla et al., 1991). These benefits have to be clarified before the two systems can be optimised. Consequently, the objectives of this study are: (1) to investigate the problems and benefits of formal and informal land administration systems in Lagos State, and; (2) to determine the relationship between the type of occupancy and level of physical development of land.

\section{Literature Review and Theoretical Framework}

\subsection{Personhood Theory and Informal Land Market}

The Personhood Theory argues that "to be a person, an individual needs some control over resources in the external environment" (Radin, 1982, p.957). It asserts that an object can be so personal to the owner that it becomes indispensable to the owner's personhood. Whereas other belongings of the person can be sold without negatively affecting his personhood, it is not so with objects that hold a certain sentimentality that essentially defines the personhood of the owners (Schnably, 1993). In this school of thought, therefore, there are links between the land, the objects on the land and the people that own the land (UN-Habitat, 2015). The personhood thinking arguably underpins communal land ownership in Nigeria since African communities generally attach sentiments, both cultural and religious, to the land in which their forefathers lived and were buried (Aina, 1990).

Until 1978, formal and informal land administration systems operated concurrently in Lagos, with the formal system being based on English laws received during the colonial period (Omirin, 1999). At this time, however, a greater proportion of today's Lagos was under customary land tenure system. The customary land tenure system follows lineage rules of inheritance, and 
intergenerational transfer of landed property rights as well as a common pool approach to the management of resources (Soludo, 2000). The broad idea of a customary land tenure system falls into three different categories: communal ownership, family ownership and individual ownership (Ikejiofor, 2009). However, the community is the ultimate owner of the land. The land is said to belong to a group of people that claim common (often mythical) ancestry. When land is parcelled out to individuals (thereby creating individual ownership, which is rare), it is frequently impossible for those individuals to dispose of the property without the consent of the head of their families or the communities (Omirin, 1999). Likewise, lands apportioned to and 'owned' by families cannot be alienated without the consent of the community. Title transfers in this system are often verbal, in the presence of witnesses, and land boundaries are largely imprecise since adjustments could be made to attain social harmony (Cousins et al., 2005). Up till the 1990s, traditional African communities in Ghana, Kenya, and Rwanda considered land as a part of the social system, and legitimate use of land was restricted to those related by birth, affinity, common residence, and social status, or some combination of these (Migot-Adholla et al., 1991), as anticipated in the Personhood Theory. Oloyede et al. (2007) viewed land administration at this time as being fair because people were able to access land for their various purposes. Rakodi and Leduka (2004) described this informal land administration process as user-friendly, effective in delivering land for housing, and socially legitimate. Ikejiofor (2006), however, reported a tendency for the informal land administration system to disfavour community members that are thought to be indolent or indifferent to the family's or community's development. During land allocation, the communities/families show preference to those members that are committed to their (the community's or family's) enlargement. Atwood (1990) posited that this system of land administration increases the outsider's risk and insecurity in land transactions. Contrastingly, Deininger and Binswanger (1999) stated that the efficiency losses associated with communal tenure systems are less significant than generally assumed. In reality, only a study that adequately articulates the merits and inadequacies of the system and observes the physical developments on land can give useful insights into the efficiency or otherwise of the system.

On the urban fringes, formal land administration creates visible contradictions due to the existence of the statutory rights of occupancy alongside the customary rights of occupancy of the indigenous communities (Adam, 2016). Based on the LUA, customary right of occupancy may be claimed by an indigenous community in three instances: (1) areas not yet acquired by the government and officially gazetted, (2) areas given to the community in excision during government land acquisition (usually in lieu of financial compensation), and; (3) areas deemed to have been given to the community by virtue of section 36 of the LUA.

In the first case, the community continues to enjoy control over her land as long as the government has not officially acquired it. When the government eventually acquires the land, the occupants of that land are compensated and evicted or allowed to regularise their titles with the government. In the second scenario, instead of acquiring the whole land belonging to a community, the government may decide to grant the community some portion, say $30 \%$ of the 
land, for the community's purposes. The community exercises right of occupancy over such a land, and may wish to sell the land, but not without the consent of the local government or the governor as the case may be [sections 21 and 22 of the LUA]. In the third case, by virtue of section 36 of the LUA, customary right of occupancy is deemed to be granted to communities or persons over agricultural and developed land being used by them in the rural areas prior to the coming into effect of the LUA. However, the person on whom the customary right of occupancy was vested by virtue of section 36 of the LUA has no right to transfer such land to another person or to subdivide it as these will constitute criminal offences (subsections 5 and 6 of section 36 of the LUA). Impliedly, such land escheat to the state upon the death of the person to whom the customary right of occupancy was vested (Smith, 2008). Evidently, informal land dealers (the communities) only have the right to transfer lands given to them by the government in the process of excision. Despite this, land buyers continue to patronise informal land dealers who act as de facto owners of rural land, with little, if any, regard to the latter's roots of title. This study will explore the demerits of such patronage to the land occupants.

\subsection{Modernisation Theory and Land Formalisation in Lagos State}

Modernisation Theory postulates that societies will progress from the traditional 'irrational' arrangements to a stage where they become 'modern' or 'rational' societies and that this progress is inevitable and irrevocable (Dibua, 2006; UN-Habitat, 2015). However, it contentiously defines 'traditional' in the negative, ignoring the positive features of traditional developing societies (Bernstein, 1971). Dibua (2006) noted that Modernisation thinking unduly advantaged Western developmental economists, who proposed the development of African countries along the lines of the Western world, without due regard to the socio-economic systems that existed in Africa. This theory asserts informal land administration system to be inefficient and advocates land commodification and the removal of customary land holdings (UN-Habitat, 2015).

In Nigeria, the single most important statute that underpins the Modernisation thinking is the LUA, which reposed freehold interest on land on the governor of each state, except lands occupied by federal government institutions. Accordingly, transactions in land are to be carried out with the consent of the governor (for land in urban areas) or the local government (for land in rural areas). In addition, several legislations have been enacted in the states of the Federation of Nigeria that have bearings on land transactions. With particular reference to Lagos State, examples include: Registration of Titles Law Cap 4 (Laws of Lagos State, 2003), Registered Land Law, Cap R1 (Laws of Lagos State, 2003), Land Instruments and Registration Laws CAP L58 (Laws of Lagos State, 2003), and the Electronic Document Management System Law 2007 (EDMSL). These laws were later consolidated into a single legislation named Lagos State Land Registration Law 2015 (Onyekwere, 2015). In Lagos State, land acquisition through government allocation requires about fourteen steps to be taken over no less than 21 days (Kolawole, 2014). Feedbacks are needed from land occupants for the government to assess the impact of its land policy improvements. The ultimate goal of land formalisation is to facilitate land development and creation of economic 
activities. Whether this has resulted from the Lagos State government's land administration policies highlighted above requires an inquiry.

After purchasing land from informal sources, the beneficiary is expected to formalise the title of the land with the government by following the Lagos State Lands Bureau's requirements. The workflow involves four processes: completion and submission of application form by the applicant; issuance of demand notice for payment by the Bureau; submission of payment receipts by the applicant; and collection of a Certificate of Occupancy $(\mathrm{C}$ of $\mathrm{O})$ by the applicant (Lagos State Lands Bureau, 2017). The cost of land regularisation is in addition to the cost of land purchase. Lagos State Lands Bureau (2017) listed the preliminary payments to include: charting, endorsement and form $1 \mathrm{C}$ fees. Later, the applicant will be required to make further payments for consent, stamp duty, capital gains tax, registration, business premises charge (if one of the parties to the transaction is a company or if the land is a business premises), direct assessment (personal income tax of the parties to the transaction) and neighbourhood charge (if applicable). This partly explains why only $2-10 \%$ of the total land area in Africa is formally recognised, with informal land markets prevailing more in peri-urban areas (Fourie, 2002).

\subsection{Issues with the Formal Land Administration System}

Cousins et al. (2005) noted that formalisation of communal property rights could undo the nature of the rights and the social relations and identities that underlie them. Boudreaux (2008) and Toulmin (2009) criticised land formalisation processes for being complex, expensive, slow to implement and to disfavour the poor. Both authors further questioned the governments' capacity and local knowledge to implement a just, large-scale national land registration system. Aina (1990) noted that the formalisation of land titles required by the LUA skewed land ownership against the poor who are not used to bureaucracy, could not afford the cost, and lacked the patience to wait for the government's land allocation process to take its course due to their urgent need to have some form of shelter erected on the land. Other researchers, like Yakub (2014), identified corrupt practices, political influence and delays in allocation as among the problems of formal land allocation in Nigeria. Broegaard (2013) noted that land titling was envisaged to protect the tenure security of the poor over their land, but that it has ended up favouring the rich more. Dowall and Clarke (1996) and Njoh (2000) observed that the formal land administration foisted on Africans was adopted from the developed countries' models and ignored the actual economic demands for space as well as the capacities of households and businesses to pay for land. Ensminger (1997) noted that the transaction cost of land formalisation might be constraining land registration processes. Particularly in Nigeria, the delays in the formal land titling processes, and sometimes the issuance of fake $\mathrm{C}$ of Os, encourage trespasses on land (Omole, 2009). These criticisms question the applicability of the Modernisation Theory in Nigeria, and this study seeks to establish their veracity based on the opinions of land occupants in Epe Local Government Area of Lagos State. The opinion of land occupants is invaluable in providing feedback on the state government's land administration policies. 
Broegaard (2013) identified the benefits of the formal land administration system in Latin America to include: tenure security and increases in the level of investment and land values. In Bogotá, real public investment per capita in the city increased by more than $650 \%$ through land formalisation (Blanco, 2011). These observations align with Njoh (2000) who argued that land commodification aids economic development and seem to support the postulations of the Modernisation Theory. However, while it is clear that both formal and informal land administration systems have merits and challenges, it is not yet settled which of them leads to a higher value development of African land. Since land title formalisation leads to land tenure security and the transaction documents are government-backed, formal landowners are better positioned to obtain capital for the physical development of their land. Thus, the government expects a higher standard of physical developments on land under formal land administration (Okafor, 2006). It has equally been argued that increased security of tenure significantly leads to higher investments in land development (Varley, 1987). A comparison of the levels of development in both formally and informally occupied land is required to validate or refute this argument.

In order to reconcile the two land administration systems, Migot-Adholla et al. (1991) recommended an enabling legal system for informal land transactions, where such transactions are recorded and recognised by law without the encumbrances typical of the existing land registration processes. This aligns with Rakodi and Leduka (2004) who suggested that the formal land administration system should be decentralised to provide for local registration of land rights. Such an arrangement should ensure a proper balance or division of labour between the public and private sectors regarding urban land development and management (Dowall \& Clarke, 1996). These suggestions sound simple, but their implementation is not. For example, the decentralisation of formal land administration will require further expensive administrative structures that do not exist currently, and for which land buyers will be made to pay indirectly (Wily, 2003).

Similarly, Durand-Lasserve et al. (2007) noted that land titling places heavy burdens on land administration agencies. Deininger and Binswanger (1999) suggested that property rights should be awarded to communities, allowing them to decide on the most suitable tenure arrangements. It can be argued that such an arrangement will precipitate litigations, and possibly lead to violent conflicts if adopted in Nigeria. Already, a good number of communal plots are the subject of litigations in the customary (and other) courts in Nigeria. Reasoning along this line, Jacoby and Minten (2006) maintained that expanding a modern property rights regime alongside an indigenous tenure system is not guaranteed to reduce insecurity and could even have the opposite effect. Deininger (2009) advocated the legal recognition of rights and institutions in the customary systems, subject to minimum conditions, and viewed such an arrangement to be superior to the premature attempts to formalise land titles. This study postulates that it is necessary to obtain and incorporate the views of land users about the merits and demerits of the two systems before any useful hybrid system can emerge. 


\section{Methodology}

\subsection{Area of Study}

The study area is Epe Local Government Area (LGA), Lagos State (Figure 1). Epe is a riverine area, covering about $965 \mathrm{~km}^{2}$. Its inhabitants are predominantly farmers involved in fishing and the cultivation of crops such as rice, cassava, oil palm, cocoa, plantains/banana, maize, ginger and sundry vegetables. Epe is a major source of supply of food to Lagos State (Mohammed et al., 2015). The rural communities in Epe include: Naforija Odomola, Epe, Ilara, Otta-Ikosi, Ejinrin, Eredo, Odoragunsen, Mojoda, Ibowon, Itoikin, Ketu, Odo-Ayandelu, Orugbo, Igbonla, Ita oko, Yegunda, Molajoyo Oke egun, Erinmope, Iganke, Araga, and Aferan among others (Ashimolowo et al., 2010). It is located about 90 kilometres to the Northeast of Lagos metropolis (Babalola \& Aina, 2004). The land scarcity in Lagos Metropolis has created an increase in demand for land in Epe and surrounding areas. Inadvertently, urban characteristics are making in-roads into the previously rural communities, thereby creating a rural-urban transition zone that keeps getting urbanised with time. This transitioning process led to the co-existence of both formal and informal land acquisition and administration processes. Due to its proximity to Lekki, Victoria Island, Ikoyi and environs, medium-income workers in these areas demand the relatively cheap land in Epe and neighbouring peri-urban local government areas for construction of residential buildings. In addition, the presence of Lagos State University (Epe Campus), banks, hospitals, and other institutions (notably, the Lekki Free Zone) attract the presence of non-natives to the area. These prospective land buyers are often exposed to the complexities of land acquisition made worse by the simultaneous existence of formal and informal land markets in the periurban area.

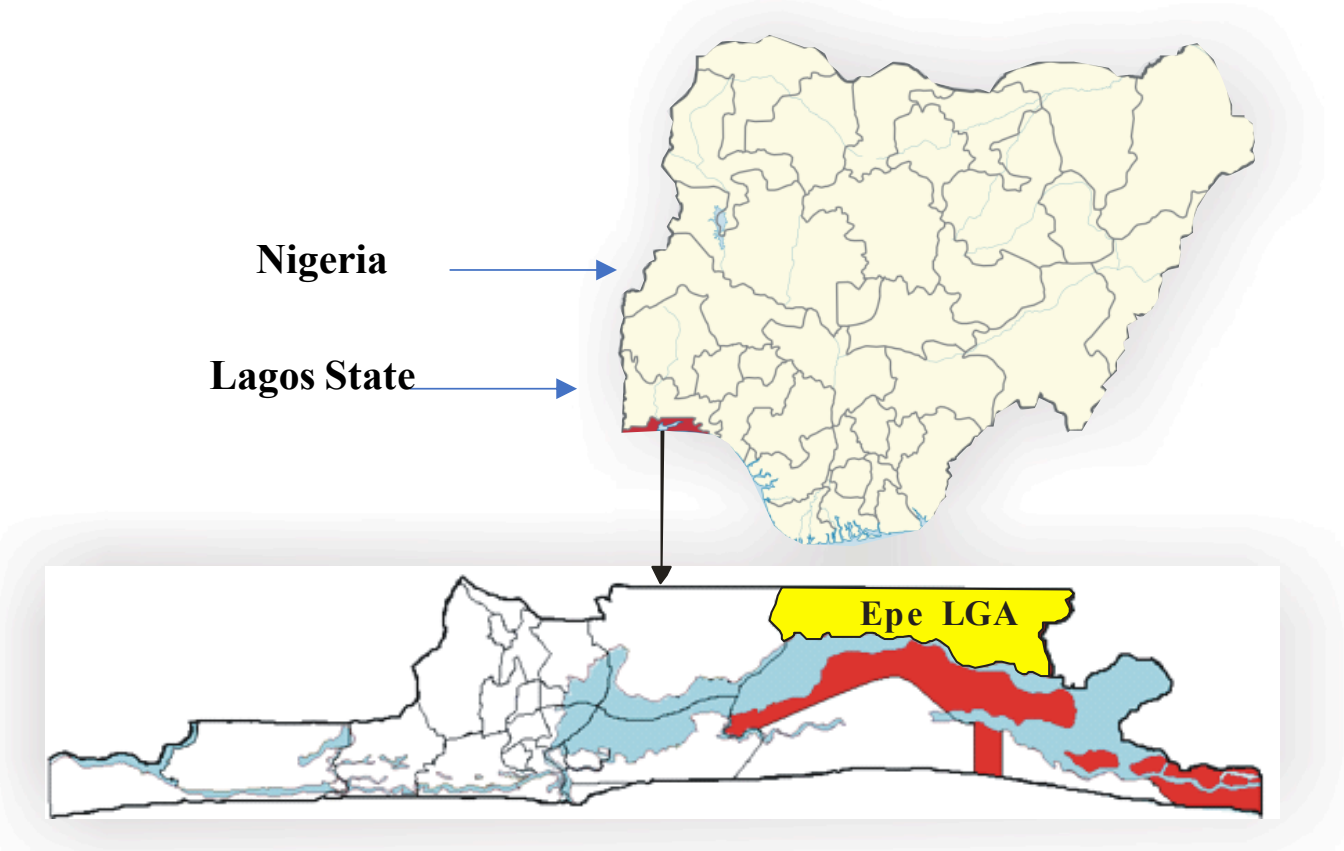

Figure 1. Map of Lagos State Showing the Location of Epe LGA Source: Adapted from Ojuri and Bankole (2013) 


\subsection{Research Design}

The purpose of this study is to evaluate the citizens' perceptions of the two land administration systems prevalent in peri-urban Epe LGA of Lagos State in order to make recommendations towards the improvement of the current land administration policies of the state. A peri-urban area was chosen for the study due to the prospect of finding a reasonable number of the two types of land occupancy in each ward of the LGA. Peri-urban areas are rural towns located close to cities which experience gradual socio-economic transformation as the town expands due to population growth (Adam, 2016). Allen (2003) noted the general lack of specificity in development planning for peri-urban areas, despite their significance as the interface between the rural and urban areas. A study such as this will help to draw attention to the need to be deliberate in land administration planning for peri-urban Epe LGA.

A cross-sectional survey design was adopted for the study. There are 19 wards in Epe LGA (Independent National Electoral Commission, 2017), out of which nine wards were randomly selected due to the level of resources available for the study. The wards were: Poka, Popo-oba, Ejirin, Lagbade, Ibonwon, Ilara, Abomiti, Ago owu and Ajaganabe. A systematic sampling technique was used to select every other building on each street for the administration of the questionnaire, and the respondents were purposively selected. Purposive sampling was used due to the pertinence of obtaining information from knowledgeable persons. It was not possible to obtain secondary data containing the names of the respondents of this study since informal land acquisitions may not be recorded at the Lagos State Lands Registry. Based on a pilot study, it was discovered that some of the respondents were sceptical about the survey, too illiterate to respond, or claimed to not have time. A similar situation was observed by the UN-Habitat (2015). As a result, the research assistants engaged in the study used the local language in some cases, to explain the intention of the survey and to read out the questions for the respondents to verbally indicate their level of agreement. This strategy, which helped to increase the number of responses to the questionnaire, is also justified because Epe is a peri-urban area which still has some relics of a rural community especially in terms of the number of aged and illiterate citizens. Additionally, it provided an opportunity for the respondents to bare their minds on other important land administration issues in the area. Forty-six (46) questionnaires were returned and used in the analyses. Sigrid et al. (2017) stated the method of questionnaire administration depends on the population under study, and that selfadministered questionnaires are subject to low response rates. To minimise social desirability bias, the respondents were first assured of the anonymity of their responses (King \& Bruner, 2000; Sigrid et al. 2017).

The study questionnaire contained problems and benefits associated with each type of land use identified through the literature review, which the respondents ranked on a Likert scale of $1=$ strongly disagree to $5=$ strongly agree. The problems of formal land administration identified and included in the questionnaire centre around bureaucratic bottlenecks in land administration, and the opacity of the land allocation processes, while the benefits were mostly tenure-security related. Informal land administration problems revolved around poor transaction documentation and insecurity of 
tenure. Its benefits identified from literature were related to the ease of transactions in land. The list of items on the questionnaire was previously cross-checked by four senior academics in the University of Benin for relevance to the study. Table 2 shows the characteristics of the respondents of the study in terms of their level of education, sex and type of occupancy.

In order to ascertain whether informal land occupancy type aided higher value land use/development, the six housing types used by the National Population Commission (Table 3) were used as proxies for the level of development of land with slight adjustments. It was considered important that the findings of the study should relate to a system of development categorisation that is already existing in the country. The value/quality of the housing types shows a progression from improvised buildings to detached building types. In accordance with the Modernisation Theory, it is expected that formal land occupants will have higher value/quality developments on their land.

The benefits and problems of the two land administration systems were ranked using mean item score (M.I.S). The M.I.S shows the relative mean weightings of the variables and enables comparisons to be made between variables in a group and across the two land administration systems. The views of land occupants with formal and informal titles were compared to elicit disparities of opinions about the two forms of land administration. It was considered important that the land users/occupants whose views were not sought in the processes leading to the enactment of the LUA 1978 should be sought in the attempt to ascertain the current impact of the policy. Logistic regression was used to investigate the relationship between the type of development on land and the type of land right possessed by the occupant. Logistic regression is useful for predicting a dichotomous outcome. Logistic regression was used due to its robustness for normality, linearity, equal variance and covariance assumptions which are required in other statistical techniques like Ordinary Least Squares (OLS) and linear discriminant analysis (Peng et al., 2002).

The absence of comprehensive data on the number of buildings and separate parcels of land in the study area may have reduced objectivity in the spread of the questionnaire for this study. Likewise, the owners of empty plots in the area were not covered by the study since no one could be found to be issued with the questionnaire. Efforts were, however, made to ameliorate this weakness by issuing the questionnaire to respondents in buildings which were originally omitted during the systematic sampling. In the end, the number of respondents $(n=46)$ was not as large as desired. The findings of the study are, however, valid for the data collected. Similar studies should be conducted in other zones of the country to test the generalisability of the findings of this study for the entire country.

\subsection{Hypothesis}

$\mathrm{H}_{\mathrm{o}}$ : There is no significant relationship between the type of land occupancy and the level of development on the land. 
Table 2: Respondent Characteristics

\begin{tabular}{lllll}
\hline & & Formal & Informal & Total \\
\hline Sex & Male & 11 & 26 & 37 \\
& Female & 6 & 3 & 9 \\
Level of education & Total & $\mathbf{1 7}$ & $\mathbf{2 9}$ & $\mathbf{4 6}$ \\
& Not educated & 3 & 9 & 12 \\
& Primary/secondary & 9 & 4 & 13 \\
& ND/NCE & 1 & 7 & 8 \\
& BSc/HND & 3 & 9 & 12 \\
& Postgraduate & 1 & 0 & 1 \\
& Total & $\mathbf{1 7}$ & $\mathbf{2 9}$ & $\mathbf{4 6}$ \\
& Landlord & 8 & $\mathbf{2 1}$ & 29 \\
& Caretaker & 9 & $\mathbf{8}$ & 17 \\
& Total & $\mathbf{1 7}$ & $\mathbf{2 9}$ & $\mathbf{4 6}$ \\
\hline
\end{tabular}

Table 3: Building Types

\begin{tabular}{ll}
\hline Code & \multicolumn{1}{c}{ Building Type } \\
\hline BT1. & $\begin{array}{l}\text { Storey building house on a separate } \\
\text { stand or yard }\end{array}$ \\
& \\
BT2 & Traditional /Hut structure \\
BT3 & Informal/ Improvised dwelling \\
BT4 & Flat in block of flats (storey building) \\
BT5 & Semi-detached house flats)/bungalow \\
BT6 & Rooms / Let in house \\
\hline & Source: National Population Commission (2006)
\end{tabular}

\section{Presentation of Results}

\subsection{Problems of Formal Land Administration}

Table 4 shows that "one needs to know someone at 'the top' to stand a chance of being allocated land" ranked first for the two groups of respondents (Table 4). Indicatively, government officials inform their own people when government land is available for allocation to citizens. This jeopardises the chances of those that are not related to the government officials in charge of the land allocation processes. While the informal occupants of land view the requirements of land registration/allocation as being unclear, hence it ranked $2^{\text {nd }}$ during the statistical analysis, the formal land occupants ranked the process as too legalistic ( $\left.2^{\text {nd }}\right)$, and ranked, "the requirements for land registration/allocation are unclear" as $11^{\text {th }}$. The informal land occupants have hardly experienced the processes of formalisation themselves. They probably have an unfounded perception of the processes of formal land administration, perhaps due to their low level of literacy. Nevertheless, the formal land occupants identify the legalistic nature of the processes as a problem. This may have been influenced by their perception of the difficult nature of the processes since "the stages/processes of land allocation are too many/long" ranked third. Additionally, "Even with $C$ of $O$ [Certificate of Occupancy], one cannot sell one's land without the governor's consent" 
(L13) ranked $4^{\text {th }}$ for the formal land occupants indicating a feeling of burdensomeness of the requirement. It ranked $10^{\text {th }}$ for the informal land occupants who do not seek any consents to sell their properties. Overall, the respondents considered government land, not as being expensive (L2 ranked $14^{\text {th }}$ and $19^{\text {th }}$ for the formal and informal occupants respectively), but as being tough to acquire due to the process and types of contacts needed to get them.

Table 4: Problems of Formal Land Administration

\begin{tabular}{|c|c|c|c|c|c|c|c|}
\hline \multirow[t]{2}{*}{ CODE } & \multirow[t]{2}{*}{ PROBLEMS } & \multicolumn{3}{|c|}{ Informal Land Users } & \multicolumn{3}{|c|}{ Formal Land Users } \\
\hline & & $\mathrm{R}$ & M.I.S & SD & $\mathrm{R}$ & M.I.S & SD \\
\hline L1 & $\begin{array}{l}\text { One needs to know someone at 'the top' to } \\
\text { stand a chance of being allocated a land }\end{array}$ & 1 & 4.55 & 0.69 & 1 & 4.59 & 0.62 \\
\hline L7 & $\begin{array}{l}\text { The requirements for land } \\
\text { registration/allocation are not clear }\end{array}$ & 2 & 4.03 & 1.5 & 11 & 3.18 & 1.55 \\
\hline L6 & $\begin{array}{l}\text { The stages/processes of land allocation and } \\
\text { registration are too many/long }\end{array}$ & 3 & 3.93 & 116 & 3 & 3.94 & 1.14 \\
\hline L5 & The processes are too legalistic & 4 & 3.9 & 1.42 & 2 & 4.06 & 0.9 \\
\hline L9 & Land is only allocated to the rich & 5 & 3.79 & 0.98 & 13 & 2.94 & 1.34 \\
\hline L4 & $\begin{array}{l}\text { Lands Bureau Staff demand for bribes for } \\
\text { carrying out official assignments }\end{array}$ & 6 & 3.72 & 1.16 & 5 & 3.65 & 1 \\
\hline L8 & $\begin{array}{l}\text { Formal land allocation does not ensure that } \\
\text { there will not be litigations in the future }\end{array}$ & 7 & 3.55 & 1.68 & 15 & 2.24 & 1.3 \\
\hline L3 & $\begin{array}{l}\text { Too many agents and middlemen in the land } \\
\text { registration process }\end{array}$ & 8 & 3.55 & 1.12 & 8 & 3.29 & 0.99 \\
\hline L10 & $\begin{array}{l}\text { One is not always allocated land in the place } \\
\text { of one's choice }\end{array}$ & 9 & 3.45 & 1.4 & 6 & 3.65 & 1.54 \\
\hline L13 & $\begin{array}{l}\text { Even with } \mathrm{C} \text { of } \mathrm{O} \text {, one cannot sell one's land } \\
\text { without the governor's consent } \\
\text { The cost of complying with formalities is too } \\
\text { highly disproportionate to the cost of the land }\end{array}$ & 10 & 3.24 & 1.21 & 4 & 3.88 & 1.11 \\
\hline L11 & itself & 11 & 3.21 & 1.57 & 7 & 3.59 & 1 \\
\hline L15 & $\begin{array}{l}\text { Type of land use is strictly stated } \\
\text { Beneficiaries are given timelines within }\end{array}$ & 12 & 3.14 & 1.48 & 10 & 3.24 & 1.39 \\
\hline L14 & which to develop their land & 13 & 3.07 & 1.22 & 14 & 2.82 & 0.95 \\
\hline L12 & The cost of land is usually too expensive & 14 & 2.93 & 1.62 & 9 & 3.24 & 1.3 \\
\hline L2 & Location of Lagos State Lands Bureau is far & 15 & 2.9 & 1.29 & 12 & 3.18 & 1.19 \\
\hline
\end{tabular}

M.I.S=Mean Item Score, $R=$ Rank

\subsection{Benefits of Formal Land Administration}

Table 5 shows the ranking of the benefits of formal land administration variables for the formal and informal land occupants. Overall, the M.I.Ss of the formal land occupants' responses are higher than those of the informal land users. This suggests that the formal land users have a higher perception of the benefits of their type of land occupancy. Possibly, the informal land users do not adequately appreciate the benefits of formal land occupancy. For the two groups of respondents, K9 ranked $1^{\text {st }}$ (informal) and $3^{\text {rd }}$ (formal) respectively. It means that an important benefit of formal land administration system is that anyone can be allocated with land anywhere irrespective of his state of origin. The low ranks of K6 ( $18^{\text {th }}$ for both groups of respondents) and $\mathrm{K} 3$ ( $19^{\text {th }}$ for both groups of respondents) indicate that the cost of processing 
documents is significant, and the registration process is not easy in the formal land administration system.

The two groups of respondents, however, tend to disagree on whether encumbrances on land are settled before an individual purchases land in the area or not. K2, thus, ranked $2^{\text {nd }}$ for the formal land occupants and $11^{\text {th }}$ for the informal land occupants. This shows the cynicism with which the informal land occupants view formal land administration. According to the respondents, whether encumbrances exist or not is a matter of luck rather than a direct benefit of the formal land administration system. This is because generally transactions in land are notorious for having issues, and informal landowners in the study area are peri-urban dwellers who may not be well informed about the formal land administration.

Table 5: Benefits of Formal Land Administration

\begin{tabular}{|c|c|c|c|c|c|c|c|}
\hline \multirow[b]{2}{*}{ CODE } & \multirow[b]{2}{*}{ BENEFITS } & \multicolumn{3}{|c|}{ Informal Land Users } & \multicolumn{3}{|c|}{ Formal Land Users } \\
\hline & & $\mathrm{R}$ & M.I.S & SD & $\mathrm{R}$ & M.I.S & SD \\
\hline K9 & $\begin{array}{l}\text { There is no favouritism or discrimination of } \\
\text { persons to own land - anyone can be } \\
\text { allocated land anywhere irrespective of his } \\
\text { state of origin } \\
\text { There are no cases of multiple ownership of }\end{array}$ & 1 & 3.72 & 1.1 & 3 & 4.29 & 0.85 \\
\hline K8 & land & 2 & 3.55 & 1.24 & 1 & 4.47 & 0.51 \\
\hline K5 & There is security of tenure & 3 & 3.48 & 1.24 & 5 & 4.24 & 0.97 \\
\hline K15 & Reduces boundary conflicts & 4 & 3.45 & 1.45 & 9 & 3.71 & 1.05 \\
\hline K10 & $\begin{array}{l}\text { The validity of title documents are } \\
\text { guaranteed by the government } \\
\text { Leads to increase in land and property }\end{array}$ & 5 & 3.41 & 1.45 & 8 & 3.76 & 1.15 \\
\hline K17 & values & 6 & 3.38 & 1.47 & 6 & 3.88 & 1.27 \\
\hline K4 & $\begin{array}{l}\text { Improves access to credit } \\
\text { Land is bought at below the fair market }\end{array}$ & 7 & 3.38 & 1.45 & 15 & 3.06 & 1.78 \\
\hline K7 & prices & 8 & 3.28 & 1.39 & 12 & 3.29 & 0.99 \\
\hline K13 & $\begin{array}{l}\text { Confers higher social status on the holders } \\
\text { Aids proper layout of buildings and urban }\end{array}$ & 9 & 3.14 & 1.55 & 16 & 3 & 1.12 \\
\hline K18 & $\begin{array}{l}\text { planning } \\
\text { Encumbrances on land are identified and }\end{array}$ & 10 & 3.14 & 1.13 & 10 & 3.53 & 1.28 \\
\hline K2 & dealt with before purchase & 11 & 3.14 & 1.48 & 2 & 4.35 & 0.79 \\
\hline K1 & The title is reliable & 12 & 3.1 & 1.59 & 4 & 4.29 & 0.77 \\
\hline K14 & Improved access to land by women & 13 & 2.83 & 1.49 & 11 & 3.41 & 1.54 \\
\hline K12 & Increases transferability of land & 14 & 2.76 & 1.35 & 14 & 3.06 & 1.14 \\
\hline K16 & $\begin{array}{l}\text { It stimulates investment in real property } \\
\text { It leads to the construction of high-quality }\end{array}$ & 15 & 2.76 & 1.62 & 17 & 2.53 & 1.62 \\
\hline K19 & buildings on the land & 16 & 2.72 & 1.33 & 13 & 3.24 & 1.15 \\
\hline K11 & $\begin{array}{l}\text { Ensures higher economic use of land } \\
\text { The cost of processing documents is }\end{array}$ & 17 & 2.66 & 1.29 & 7 & 3.82 & 1.07 \\
\hline K6 & insignificant & 18 & 2.59 & 1.12 & 18 & 2.06 & 1.3 \\
\hline K3 & Title registration is easy and smooth & 19 & 2.14 & 1.3 & 19 & 1.76 & 0.9 \\
\hline
\end{tabular}

M.I.S=Mean Item Score, $R=$ Rank

\subsection{Problems of Informal Land Administration}

The two groups of respondents agree that an additional settlement is required before one can build on an informal land (Table 6). This variable (P9) ranked $1^{\text {st }}$ and $3^{\text {rd }}$ for the informal and formal respondents respectively. The two 
groups of respondents appear to differ on a number of other points. For instance, while the formal land occupants appear to be more concerned about the fact that the authority to sell the land does not lie with one person (ranked $1^{\text {st }}$ ), this item (P2) is ranked $9^{\text {th }}$ for the informal land users. The informal land occupants were more concerned about the multiple-sale of land to different persons which could create a conflict (P10 ranked $2^{\text {nd }}$ for the informal land occupants). This signifies the concern of the informal land occupants about the security of tenure of their land. The respondents agree that informal land administration system does not discriminate against women hence this variable ranked $17^{\text {th }}$ (informal) and $15^{\text {th }}$ (formal).

Table 6: Problems of Informal Land Administration

\begin{tabular}{|c|c|c|c|c|c|c|c|}
\hline \multirow[b]{2}{*}{ CODE } & \multirow[b]{2}{*}{ PROBLEMS } & \multicolumn{2}{|c|}{$\begin{array}{l}\text { Informal } \\
\text { Users }\end{array}$} & \multirow{2}{*}{$\begin{array}{l}\text { Land } \\
\text { SD }\end{array}$} & \multicolumn{3}{|c|}{ Formal Land Users } \\
\hline & & $\mathrm{R}$ & M.I.S & & $\mathrm{R}$ & M.I.S & SD \\
\hline P9 & $\begin{array}{l}\text { An additional settlement is required } \\
\text { before one can build on the land } \\
\text { Different persons may sell the same }\end{array}$ & 1 & 4.69 & 0.47 & 3 & 4.06 & 0.9 \\
\hline $\mathrm{P} 10$ & $\begin{array}{l}\text { parcel of land to different individuals } \\
\text { thereby creating a conflict }\end{array}$ & 2 & 4.03 & 1.09 & $\begin{array}{l}1 \\
1\end{array}$ & 3.53 & 0.94 \\
\hline P17 & $\begin{array}{l}\text { There is poor record keeping and } \\
\text { documentation }\end{array}$ & 3 & 3.72 & 1.39 & 2 & 4.24 & 1.09 \\
\hline P1 & $\begin{array}{l}\text { Roots of titles are difficult to ascertain } \\
\text { The requirement for regularisation with } \\
\text { the government after purchase makes it }\end{array}$ & 4 & 3.66 & 1.34 & 4 & 4.06 & 0.9 \\
\hline P8 & very expensive & 5 & 3.62 & 1.29 & 8 & 3.71 & 1.4 \\
\hline P4 & $\begin{array}{l}\text { Boundaries are usually contentious } \\
\text { There is a requirement for immediate } \\
\text { development of the property to prevent } \\
\text { the resell of the property by the }\end{array}$ & 6 & 3.59 & 1.68 & 7 & 3.76 & 1.39 \\
\hline P11 & $\begin{array}{l}\text { community } \\
\text { The process of acquisition is not }\end{array}$ & 7 & 3.52 & 1.38 & $\begin{array}{l}4 \\
1\end{array}$ & 2.53 & 1.5 \\
\hline P5 & $\begin{array}{l}\text { straightforward } \\
\text { The authority to sell land does not lie }\end{array}$ & 8 & 3.24 & 1.5 & 3 & 2.88 & 1.41 \\
\hline $\mathrm{P} 2$ & $\begin{array}{l}\text { with one person } \\
\text { Title documents are not acceptable for }\end{array}$ & 9 & 3.14 & 1.48 & $\begin{array}{l}1 \\
1\end{array}$ & 4.29 & 0.77 \\
\hline P13 & $\begin{array}{l}\text { mortgage } \\
\text { Often results in improper layout of }\end{array}$ & 10 & 2.9 & 1.52 & 6 & 1.94 & 0.9 \\
\hline P16 & buildings & 11 & 2.83 & 1.47 & $\begin{array}{l}6 \\
1\end{array}$ & 3.82 & 1.01 \\
\hline P7 & Title documents are not reliable & 12 & 2.79 & 1.61 & 0 & 3.65 & 1.32 \\
\hline P3 & $\begin{array}{l}\text { There is serious insecurity of tenure } \\
\text { Boundaries are adjusted after the sale of }\end{array}$ & 13 & 2.72 & 1.51 & 5 & 4 & 1.17 \\
\hline P14 & $\begin{array}{l}\text { land } \\
\text { Other things like drinks are required }\end{array}$ & 14 & 2.69 & 1.69 & $\begin{array}{l}9 \\
1\end{array}$ & 3.65 & 1.32 \\
\hline P6 & $\begin{array}{l}\text { besides money to close a deal } \\
\text { The buyer is required to continue to pay } \\
\text { ground rent to the original owner of the }\end{array}$ & 15 & 2.69 & 1.44 & 2 & 3 & 1.37 \\
\hline P12 & land & 16 & 2.48 & 1.27 & $\begin{array}{l}7 \\
1\end{array}$ & 1.82 & 1.13 \\
\hline $\mathrm{P} 15$ & The system discriminates against women & 17 & 2.38 & 1.27 & 5 & 2.12 & 1.45 \\
\hline
\end{tabular}

M.I.S=Mean Item Score, $R=$ Rank 


\subsection{Benefits of Informal Land Administration}

Informal land occupants seem to believe that land acquisition from informal sources offers them the advantage of purchasing land in the place of their choice (S2 ranked $1^{\text {st }}$ for the informal land occupants). On the contrary, S2 ranked $6^{\text {th }}$ for the formal land occupants which indicates that formal land occupants comparatively have lower control over where they are allocated land. Both groups of respondents agree that informal land documentation is relatively cheap (S4 ranked as $1^{\text {st }}$ and $2^{\text {nd }}$ for the formal and informal land occupants respectively). As shown in Table 7, the respondents' opinions seem to differ on the cost of informal land. The formal land users consider it to be expensive (rank $=12^{\text {th }}$ ), while the informal land users consider it to be relatively inexpensive $\left(\operatorname{rank}=3^{\text {rd }}\right)$.

Table 7: Benefits of Informal Land Administration

\begin{tabular}{|c|c|c|c|c|c|c|c|}
\hline \multirow[b]{2}{*}{ CODE } & \multirow[b]{2}{*}{ BENEFITS } & \multicolumn{3}{|c|}{ Informal Land Users } & \multicolumn{3}{|c|}{ Formal Land Users } \\
\hline & & $\mathrm{R}$ & M.I.S & SD & $\mathrm{R}$ & M.I.S & $\mathrm{SD}$ \\
\hline $\mathrm{S} 2$ & Land is purchased in the place of one's choice & 1 & 4.07 & 1.22 & 6 & 3.65 & 1.41 \\
\hline S4 & The cost of documentation for land purchase is relatively cheap & 2 & 3.76 & 1.15 & 1 & 4.24 & 1.15 \\
\hline S1 & Land is relatively cheap & 3 & 3.69 & 1.47 & 12 & 2.59 & 1.28 \\
\hline S9 & $\begin{array}{l}\text { Helps early access to land and commencement of building } \\
\text { construction by the poor }\end{array}$ & 4 & 3.66 & 1.17 & 7 & 3.47 & 1.12 \\
\hline S7 & The buyer is free to decide on what to do on the land & 5 & 3.62 & 1.37 & 3 & 3.94 & 1.14 \\
\hline S6 & No timeline is given within which to develop the land & 6 & 3.41 & 1.38 & 4 & 3.88 & 1.22 \\
\hline S11 & $\begin{array}{l}\text { Disputes are more easily resolved by the chiefs and stools through } \\
\text { alternative dispute resolution mechanisms }\end{array}$ & 7 & 3.34 & 1.26 & 2 & 3.94 & 0.9 \\
\hline S5 & $\begin{array}{l}\text { The process and duration of land purchase is very short and stress- } \\
\text { free }\end{array}$ & 8 & 3 & 1.39 & 10 & 3.24 & 1.25 \\
\hline S10 & $\begin{array}{l}\text { The system is decentralised, enabling land matters to be handled } \\
\text { separately by different authorities }\end{array}$ & 9 & 2.93 & 1.49 & 9 & 3.35 & 0.86 \\
\hline S12 & $\begin{array}{l}\text { Original owners of land sell land to people known to them and are } \\
\text { therefore able to preserve ancient monuments of their societies }\end{array}$ & 10 & 2.9 & 1.59 & 11 & 3.24 & 1.39 \\
\hline S8 & $\begin{array}{l}\text { It preserves social harmony and preservation of existing culture } \\
\text { within the society }\end{array}$ & 11 & 2.83 & 1.54 & 8 & 3.47 & 1.23 \\
\hline S3 & There may be provision for instalment payment & & 2.66 & 1.56 & 5 & 3.76 & 1.35 \\
\hline S13 & $\begin{array}{l}\text { Sometimes land is sold on the condition that the buyer will build } \\
\text { a town hall for the community thereby aiding development }\end{array}$ & & 2.62 & 1.47 & 13 & 2.53 & 1.01 \\
\hline
\end{tabular}

M.I.S=Mean Item Score, $R=$ Rank

Perhaps, to formal land occupants, informal land ownership is expensive in the long run when the risks involved are accounted for, but the informal landowners may not perceive this. Additionally, unlike informal land, formal land is sold at below market prices by the government. On whether the buyers 
of informal land are requested to carry out other forms of developments for the community, the respondents agreed that this is not the case since S13 ranked $13^{\text {th }}$ for both groups.

\subsection{Relationship Between Level of Development and Type of Land Occupancy}

It was hypothesised that a significant relationship exists between the type of land occupancy and the level of development of land in the research area. To test this hypothesis, logistic binary regression was carried out to relate the type of building structure on each land to the type of land occupancy. It was intended to examine whether the type of land occupancy (i.e. whether formal or informal) determines the level of development of the site (proxied by the type of structure on the ground). The indices of goodness of fit, Cox and Snell $\mathrm{R}^{2}$ and Nagelkerke $\mathrm{R}^{2}$, which represent pseudo $\mathrm{R}^{2}$ showed that the predictors only predicted $13.7 \%$ to $18.7 \%$ of the variation in the type of land occupancy (Table 8). This means that the level of physical development on site is poorly related to the type of occupancy of the land user. The inclusion of the variables was, however, unable to improve the correct classification rate beyond the $63 \%$ observed in the null model. Table 9 shows that none of the predictors significantly influenced the odds of the type of land occupancy ( $p>0.05)$. Equally, the omnibus tests of model coefficients showed $p$-values of $>0.05$. It was, therefore, concluded that the level of land development is not related to the type of land occupancy in the area.

Table 8: Logistic Binary Analysis Results

\begin{tabular}{|c|c|c|c|c|c|}
\hline \multicolumn{3}{|c|}{ Observed } & \multicolumn{3}{|c|}{ Predicted } \\
\hline & & & \multicolumn{2}{|c|}{ LANDADMIN } & \multirow{2}{*}{$\begin{array}{c}\text { Percentage } \\
\text { Correct }\end{array}$} \\
\hline & & & 0 & 1 & \\
\hline \multirow[t]{3}{*}{ Step 0} & LANDADMIN & 0 & 29 & 0 & 100 \\
\hline & & 1 & 17 & 0 & 0 \\
\hline & Over & 1 Percentage & & & 63 \\
\hline \multirow[t]{5}{*}{ Step 1} & LANDADMIN & 0 & 29 & 0 & 100 \\
\hline & & 1 & 17 & 0 & 0 \\
\hline & Over: & 1 Percentage & & & 63 \\
\hline & Omnibu & Tests of Model Coeffi & ents & & \\
\hline & & Chi-square & df & Sig. & \\
\hline \multirow[t]{3}{*}{ Step 1} & Step & 6.758 & 5 & 0.239 & \\
\hline & Block & 6.758 & 5 & 0.239 & \\
\hline & Model & 6.758 & 5 & 0.239 & \\
\hline & & del Summary & & & \\
\hline \multirow[t]{2}{*}{ Step } & $-2 \log$ & Cox \& Snell R Square & Nagelkerke & & \\
\hline & likelihood & & R Square & & \\
\hline 1 & $53.845^{\mathrm{a}}$ & 0.137 & 0.187 & & \\
\hline
\end{tabular}


Table 9: Variables in the Equation

\begin{tabular}{rccccccc}
\hline & & B & S.E. & Wald & df & Sig. & Exp(B) \\
\hline Step 1a & bt & & & 0.645 & 5 & 0.986 & \\
& bt (1) & -21.069 & 40192.97 & 0 & 1 & 1 & 0 \\
& bt (2) & -21.069 & 17974.84 & 0 & 1 & 0.999 & 0 \\
& bt (3) & -0.965 & 1.265 & 0.582 & 1 & 0.446 & 0.381 \\
& bt (4) & -0.272 & 0.827 & 0.108 & 1 & 0.742 & 0.762 \\
& bt (5) & -0.049 & 0.797 & 0.004 & 1 & 0.951 & 0.952 \\
& Constant & -0.134 & 0.518 & 0.067 & 1 & 0.796 & 0.875 \\
\hline
\end{tabular}

a. Variable(s) entered on step 1: bt.

\section{Discussion}

A major problem of the formal land administration system in Lagos State identified by the respondents is that one needs to know someone at 'the top' (this refers to government officials in senior positions) to be allotted land. Land allocation is usually shrouded in secrecy such that the general public is mostly unaware when land is available for allocation to the public. Sometimes, land is acquired by the government after applications have been made, thus precluding the beneficiaries' prior knowledge of the location of the land to be allotted to them. The findings of this study, like Yakub's (2014), suggest that the processes are unclear and too legalistic. Yakub found that, in Kaduna State, formal land administration is tedious and complicated. Unlike Lagos State, Kaduna State is yet to implement an Electronic Document Management System (EDMS) in its land administration system. Also, the finding that the stages/processes of land allocation and registration are too many/long aligns with Jones (2010) who noted that similar processes exist in Southeast Asia, where numerous signatories are necessary before formal land occupancies are approved.

Major problems associated with land acquired from informal sources are the requirement for an additional settlement of the community before one can build on the land and poor record keeping. Unfortunately, the LUA, or more appropriately its implementation, has not stopped the continuous extortion of land buyers after informal land transactions. The unwillingness of communities to let go of their land is what leads to this form of behaviour. This supports the thinking of the Personhood Theory (Schnably, 1993; UNhabitat, 2015) that the indigenous communities attach emotional sentiments to their land (Omirin, 1999). Osemwota (1989) found that traditional chiefs neither felt threatened by nor opposed to formal land administration, which is at variance with the Personhood Theory and the result of this study. Osemwota's (1989) finding may be because the government had compensated the chiefs financially or by giving them land over which they could exercise control.

Transaction instruments used in the conveyance of informal land are not government-backed, which creates room for multiple-sale of the same parcel of land. Additionally, the transactions are not properly recorded to enable buyers know which land is free of encumbrances, and which land is not. This study further shows that women are culturally unhindered from negotiating 
and acquiring land directly through the informal process in the study area. Understandably, this is because women are allowed to inherit land in the Yoruba custom (from their fathers, husbands, sons, or other family members). The custom also permits them the independence to acquire all forms of property including land (Aluko, 2015), and there are no Nigerian laws refraining them from enjoying this right. However, other social and economic hindrances may limit women's ability to exercise this right in practice (Staveren \& Odebode, 2007). In contrast to the result of this study with regards to women's access to informal land, Binswanger-Mkhize and Deininger (2009) and Hanstad et al. (2009), reported that women were previously not allowed to acquire land directly and that the government of India had to establish a special programme for the direct negotiation of land acquisition by women in the country. It is illogical, however, to stretch the interpretation of this result to other culturally, socially and economically diverse contexts.

The respondents in this study believe that one of the benefits of formal land administration is that it eliminates favouritism and discrimination in land allocation. Nigeria is a multi-ethnic and multi-cultural state with historical tensions based on identity markers. Therefore, a system that eliminates favouritism on the grounds of heritage or identity should aid the spread of development in line with the Modernisation Theory (UN-Habitat, 2015). Equitable access to land is part of the vision of the Lagos State Lands Bureau as stated in their website, and forms one of the core objectives in land formalisation processes all over the world (see Machira, 2009; Broegaard, 2013). It is to be noted, however, that this finding does not imply that the Land Use Act's objective (of making every Nigerian an owner of land) has been achieved.

This study supports Omirin's (1999) suggestion that the LUA may have succeeded in removing some of the difficulties associated with title/tenure security as the respective respondents believe that tenure security is enhanced, while the formal land administration eliminates cases of multiple claims to the ownership of land. Overall, the findings of this study imply that while some of the visions of the LUA have been achieved in the study area, a lot needs to be done to make the processes of land formalisation transparent and user-friendly.

The informal land occupants believe that it is an advantage to buy land in the place of one's choice. There is a very slim chance of being allotted land in a place of one's choice under the formal system of land administration. This is because the government acquires land for allotment to the citizens in a place of its choice without any inputs whatsoever from the prospective land users. To further compound this problem, the more desirable locations in government-acquired land are often allocated to the rich and influential. While both types of respondents believe that the cost of documentation for informal land is relatively cheaper, the formal land occupants feel that informal land is more expensive to acquire. This view may be stemming from the fact that government land is sold below the fair market value (Lagos State Government Lands Bureau, 2017) compared with the informal lands that are sold at fair market values. 
The findings of this study did not support Modernisation Theory's postulation that land formalisation is associated with higher value property development (UN-Habitat, 2015). It could not be proved that there are better developments on lands held under the formal land administration system. Evidence from this study failed to corroborate the argument that land titling produces bankable title documents with which the owners (necessarily) obtain loans for land development (Jones, 2010). A possible explanation is that collateralised lending has not taken hold in the study area (Jacoby \& Minten, 2006), which renders government's policy in this regard ineffective (Dowall \& Clark, 1996). Thus, Ensminger's (1997) opinion that the expectation in the formalisation of land titles in Africa has not been met is supported by this study. This finding lends credence to the idea of evolving a hybrid of the two land administration systems in which the benefits of the two are harnessed and optimised, while the weaknesses are eliminated as argued by Ikejiofor (2006). An incentive exists for this. For instance, a relationship already exists between the two systems which has led to the informal system adopting some of the rules of the formal system and thereby overcoming some of its (the informal system's) shortcomings (Ikejiofor, 2006). However, further research is required to understand what such a hybrid system would look like.

\section{Conclusions and Policy Implications}

An efficient land administration system is at the core of the requirements for economic development in Nigeria. The objectives of this study were (1) to investigate the problems and benefits of formal and informal land administration systems in Lagos State, and; (2) to determine the relationship between the type of occupancy and level of physical development of land. This study elicited the land occupants' perspective on the issues surrounding the predominant land administration approaches in Nigeria. It brought to the fore the desirable and undesirable characteristics of the two land administration systems (formal and informal), exposing similarities and differences in the opinions of the formal and informal land occupants in the study area. As a result, the government of Lagos State can be aware of subsisting issues in the overall administration of land in the state and have a useful basis for formulating future land administration policies.

A key problem with the formal land administration system is that "one needs to know someone at 'the top' to stand a chance of being allocated a land'. Impliedly, the process of land allocation in the state is still opaque despite government's interventions in the land administration system. The fact that the stages/processes of land allocation and registration are too many/long further attests to this. The Lagos State government should strengthen measures aimed at easing the process of land allocation/formalisation, perhaps by reducing the number of signatories required in the process of obtaining the governor's consent. Most citizens will continue to view land formalisation in Lagos State with disdain unless the government eliminates these problems. The government should take steps to make the process of land allocation transparent. Equitable access to land demands that there will be equal access to land availability information. This being said, the most important benefit of the formal land administration system is that there is no favouritism/discrimination of persons to own land on the basis of ethnicity anyone can be allocated land anywhere irrespective of their state of origin. It 
implies that there are no racial discriminations in the allocation of land and formalisation of land titles in Lagos State. This policy should be maintained and further strengthened by the Lagos State government.

It was found that "after purchase, an additional settlement is required before one can build on the land" is a major problem of the informal land administration system in the study area based on the views of the land occupants. Demands for extra payments and different forms of buffeting suffered by informal land occupants will continue to expose investors to fraudsters and create uncertainties in the land market of the research area if not curbed. The government should act to stop informal land dealers from making any form of additional demands on land buyers after purchase, especially, while developing the land. This will raise investor confidence and prevent deviants from making repeated requests for money from land occupants. More concerted efforts should be expended in the implementation of the Lagos State Properties Protection Law 2016, which has the primary purpose of curbing the activities of land grabbing miscreants.

One of the key benefits of the informal land administration system is that buyers choose the location of the land they want to buy, unlike the formal land administration system where the government allots an individual land in the place of government's choice. The adoption of this feature in the formal land administration system is highly recommended. Measures should be put in place to enhance land buyers' ability to choose the location and plot of land to be allotted in the formal land administration system, at least, on a first come, first served basis. A transparent system of land allocation should make it possible for land users' inputs to be accommodated in the land allocation process.

The study hypothesised that there is no significant relationship between the type of land occupancy and the level of development on land. Data obtained for the study supported the acceptance of the hypothesis. Thus, it is concluded that neither of the two theories - the Modernist and the Personhood - is superior to the other in explaining the level of physical development on land in the study area. This means that formally held land is not better developed than the informally held ones. Informal land administration, therefore, does not constrain land development more than formal land administration, at least not in Epe LGA. The benefits of informal land administration revealed in this study (such as accommodating land buyers' choices in the land allocation process, and low cost of transaction in land) should, as a result, be targeted in future land administration reforms in Lagos State.

\section{References}

Adam, A. G. (2016). Urbanisation and the Struggle for Land in the PeriUrban Areas of Ethiopia. In Annual Bank Conference on Africa. [Online]. Available at:

http://cega.berkeley.edu/assets/miscellaneous_files/22_ABCA_Urb anization-research_paper-ABCA.pdf (Accessed $1^{\text {st }}$ August 2018). 
Agbola, T. (1998). The Housing of Nigerians: A Review of Policy Development and Implementation in the Housing Sector (No. 14). Development Policy Centre.

Aina, T. A. (1990). The Urban Poor and the Commercialisation of Land in Nigeria. In Small Town Africa: Studies in Rural-urban Interaction. J. Baker (ed.), Nordiska afrikainstitutet, Sweden, pp.192-208.

Ajanlekoko, J. S. (2001). Sustainable Housing Development in Nigeria - The Financial and Infrastructural Implication, Paper presented at the International Conference on Spatial Information for Sustainable Development; 2-5 October 2001, Nairobi-Kenya.

Allen, A. (2003). Environmental Planning and Management of the Periurban Interface: Perspectives on an Emerging Field. Environment and Urbanisation, 15(1), pp.135-148.

Aluko, B. T., Olaleye, A. \& Amidu, A. (2004). Problems of Land Delivery for housing development in Lagos state, Nigeria. Paper presented at the International Symposium on Globalisation and Construction Proceedings, AIT Conference Centre, 17-19 November 2004, Bangkok- Thailand, pp.601-610.

Aluko, Y. A. (2015). Patriarchy and Property Rights Among Yoruba Women in Nigeria. Feminist Economics, 21(3), pp.56-81.

Ashimolowo, O. R., Aromolaran, A. K. \& Inegbedion, S. O. (2010). Child Street-Trading Activities and Its Effect on the Educational Attainment of Its Victims in Epe Local Government Area of Lagos State. Journal of Agricultural Science, 2(4), pp.211-220.

Atwood, D. (1990). Land Registration in Africa: The Impact on Agricultural Production. World Development, 18(5), pp.659-71.

Ayeni, A. O. (2016). Increasing Population, Urbanization, and Climatic Factors in Lagos State, Nigeria: The Nexus and Implications on Water Demand and Supply. Journal of Global Initiatives 11(2), pp.69-87.

Babalola, S., \& Aina, O. (2004). Community and Systemic Factors Affecting the Uptake of Immunisation in Nigeria: A Qualitative Study in Five States. 1-5, PATHS, Abuja.

Bah, M. Cisse, S., Diyamett, B., Diallo, G., Lerise, F., Okali, D., Okpara, E., Olawoye, J. \&Tacoli, C. (2003). Changing Rural-Urban Linkages in Mali, Nigeria And Tanzania. Environment and Urbanization, 15(1), pp.13-24.

Bernstein, H. (1971). Modernisation Theory and The Sociological Study of Development. The Journal of Development Studies, 7(2), pp.141-160.

Binswanger-Mkhize, H. P. \& Deininger, K. (2009). History of Land Concentration and Redistributive Land Reforms. In Agricultural Land Redistribution Toward Greater Consensus, H. P. BinswangerMkhize, C. Bourguignon, and R. van den Brink, (eds.) The World Bank, Washington D. C. pp. 45-86.

Blanco, A. G. (2011). Discourses of Land Allocation and Natural Property Rights: Land Entrepreneurialism and Informal Settlements in Bogotá, Colombia. Planning Theory, 11(1), pp.20-43.

DOI: $10.1177 / 1473095211403124$.

Boudreaux, K. (2008). Urbanisation and Informality in Africa's Housing Markets. Economic Affairs, 28(2), pp.17-24.

Broegaard, R. B. (2013). Biting the Barefoot: Land Titles and Tenure Security in the Context of Inequality. Danish Institute for 
International Studies Report 2013. [Online]. 32. Available at: https://www.diis.dk/files/media/publications/import/rp201332 land-titles rikke-b-broegaard web.pdf (Accessed $17^{\text {th }}$ July 2017).

Cousins, B., Cousins, T., Hornby, D., Kingwill, R., Royston, L. \& Smit, W. (2005). Will Formalising Property Rights Reduce Poverty in South Africa's 'Second Economy'? Questioning the Mythologies of Hernando De Soto. PLAAS Policy Brief, 18, pp.1-6.

Deininger, K. \& Binswanger, H. (1999). The Evolution of the World Bank's Land Policy: Principles, Experience, And Future Challenges. The World Bank Research Observer, 14(2), pp.247-276.

Deininger, K. (2009). Monitoring and Evaluation of Land Policies and Land Reform. In Agricultural land redistribution: towards greater consensus, H. P. Binswanger-Mkhize, C. Bourguignon and R. van den Brink (eds.) The World Bank, Washington, D. C. pp.397-439.

Department for International Development. (2010). Land Administration Reform Administration, Registration and Regularisation. [Online]. Available at: http://www.sparc-nigeria.com/SJG2/ (Accesses 28 $8^{\text {th }}$ July 2017).

Dibua, J. I. (2006). Modernisation and The Crisis of Development in Africa. Ashgate Publishing, Hampshire.

Dowall, D. E. \& Clarke, G. (1996). A framework for reforming urban land policies in developing countries, World Bank, Washington, D.C.

Durand-Lasserve, A., Fernandes, E., Payne, G. \& Rakodi, C. (2007). Social and economic impacts of land titling programmes in urban and periurban areas: a review of the literature. In World Bank Urban Research Symposium, Washington DC. [Online]. Available at: https://www.researchgate.net/profile/Alain_DurandLasserve/publication/228699667_Social_and_economic_impacts_of land titling programmes in urban and periurban_areas_A_review of the literature/links/54db4c5a0cf2ba88a 6 8fb659.pdf (Accessed 30 ${ }^{\text {th }}$ July 2017).

Egunjobi, L. \& Adebayo, A. (2016). Incidence of Building Collapse in Nigeria: Case of Lagos State. International Journal of Sustainable Development, 9(3), pp.109-114.

Ensminger, J. (1997). Changing Property Rights: Reconciling Formal and Informal Rights to Land in Africa. In The Frontiers of the New Institutional Economics, J. N. Drobak and J. V. C. Nye, (eds). Academic Press, San Diego, pp.165-196.

Fourie, C. (2002). Designing Viable Land Administration Systems: Options and Challenges, Paper Presented at World Bank Regional Workshop on Land Issues for Africa and the Middle East, $29^{\text {th }}$ April- $2^{\text {nd }}$ May 2002. Kampala- Uganda.

Hanstad, T., Nielsen, R., Vhugen, D. \& Haque, T. (2009). Learning from Old and New Approaches to Land Reform in India. In Agricultural Land Redistribution Toward Greater Consensus, H. P. BinswangerMkhize, C. Bourguignon and R. van den Brink (eds). World Bank, Washington D. C. pp.241-263.

Ikejiofor, C. U. (2006). Integrative Strategies or Functional Interface? Emerging Trends in Land Administration in Contemporary Enugu, Nigeria. International Development Planning Review, 28(2), pp.137158. 
Ikejiofor, U. C. (2009). Planning Within a Context of Informality: Issues and Trends in Land Delivery in Enugu, Nigeria, Case Study Prepared for Revisiting Urban Planning: Global Report on Human Settlements 2009. [Online]. Available at: http://www.unhabitat.org/grhs/2009 (Accessed 19 ${ }^{\text {th }}$ July 2017).

Independent National Electoral Commission. (2017). Polling Units. [Online]. Available at: http://www.inecnigeria.org/?page $\mathrm{id}=20$ (Accessed $11^{\text {th }}$ August 2017).

Jacoby, H. \& Minten, B. (2006). Land Titles, Investment, and Agricultural Productivity in Madagascar: A Poverty and Social Impact Analysis. World Bank, Washington, D.C. [Online]. Available at: https://openknowledge.worldbank.org/handle/10986/12661 (Accessed $11^{\text {th }}$ August 2017).

Jones, D. S. (2010). Land Registration and Administrative Reform in Southeast Asian States: Progress and Constraints. International Public Management Review, 1(11), pp. 67-89.

King, M. F. \& Bruner, G. C. (2000). Social Desirability Bias: A Neglected Aspect of Validity Testing. Psychology \& Marketing, 17(2), pp.79103.

Kolawole, Y. (2014). Procedures, Requirements for Obtaining C of O in Lagos State. Vanguard Newspaper. [Online]. Available at: https://www.vanguardngr.com/2014/04/procedures-requirementsobtaining-c-o-lagos-state/ (Accessed $13^{\text {th }}$ December 2017).

Lagos State Government Lands Bureau. (2017). Governor's Consent. [Online]. Available at:

http://landsbureau.lagosstate.gov.ng/2017/05/17/governors-consent/ (Accessed $8^{\text {th }}$ October 2017).

Magbogunje, A. L. (2005). Beyond Housing Delivery: The Challenge of Infrastructure Provision and Orderly Urban Development in Nigeria, SOFF 5th Annual Distinguished Guest Lecture Series and Endowment Fund, Lagos.

Machira, S. (2009). Pilot-Testing a Land Distribution Program in Malawi. In Agricultural Land Redistribution Toward Greater Consensus, H. P. Binswanger-Mkhize, C. Bourguignon\& R. van den Brink (eds.) World Bank, Washington D. C. pp. 367-395.

Migot-Adholla, Hazell, S., Blarel, B. \& Place, F. (1991). Indigenous Land Rights Systems in Sub-Saharan Africa: A Constraint on Productivity? The World Bank Economic Review, 5(1), pp.155-175

Mohammed, U. S., Iyiola, A. S., \& Usman, R. K. (2015). Production Analysis of Catfish Farming in Epe Local Government Area of Lagos State, Nigeria. PAT, 11(2), pp.153-161.

National Population Commission. (2006). Housing Characteristics and Amenities Table: Priority Tables (LGA) [Online], Volume 2. Available at: http://catalog.ihsn.org/index.php/catalog/3340 (Accessed $9^{\text {th }}$ December 2017).

Njoh, A. J. (2000). Continuity and Change in Cameroonian Land Policy. Planning Perspectives, 15(3), pp.241-265.

DOI: $10.1080 / 026654300407454$

Njoku, I.F. (2004). The Information Needs and Information-Seeking Behaviour of Fishermen in Lagos State, Nigeria. The International Information \& Library Review, 36(4), pp.297-307. 
Nubi, G. T. \& Ajoku, C. (2011). Nexus Between Effective Land Management and Housing Delivery in Lagos. Environment and Urbanization, 23(1), pp.285-303.

Ojuri, O. \& Bankole, O. (2013). Groundwater Vulnerability Assessment and Validation for a Fast-Growing City in Africa: A Case Study of Lagos, Nigeria. Journal of Environmental Protection, 4(5), pp.454-465. DOI: 10.4236/jep.2013.45054.

Olokoyo, F. O., George, T. O., Efobi, U. \& Beecroft, I. (2014). Land Deals, Household Attributes and Quality of Life: The Untold Story from a Rural Community in Nigeria. Paper Presented at the 17th Annual Conference on Global Economic Analysis "New Challenges in Food Policy, Trade and Economic Vulnerability" the Centre for Global Trade Analysis Purdue University (GTAP), 18-20 June 2014, DakarSenegal.

Oloyede, S. A., Ajibola, M. O. \& Oni, A. O. (2007). Informal Land Delivery System in Lagos State, Nigeria. Journal of Land Use and Development Studies, 3(1), pp.140-14.

Omirin, M. M. (1999). Land Tenure System versus House Builders' Requirements for Security: The Lagos Experience. The Lagos Journal of Environmental Studies, 2(1), pp.41-52.

Omole, F. K. (2009). Land Use Violations, Implications for Sustainable Development: The Case of the Federal Capital City, Abuja, Nigeria. Current Research Journal of Social Sciences, 1(1), pp.31-37.

Onyekwere, J. (2015). Nigeria: Parley on Lagos Land Registration Law. The Guardian. [Online]. Available at:

http://allafrica.com/stories/201512081119.html $\quad$ (Accessed $8^{\text {th }}$ October 2017).

Osemwota, O. (1989). Ownership, Control and Management of Land in Bendel State, Nigeria: The Changing Role of Traditional Rulers. Land Use Policy, 6, pp.75-83.

Oteri, A. U. \& Ayeni, R. A. (2016). The Lagos Megacity. [Online]. Available at: http://eaumega.org/wp-content/uploads/2016/05/EN-LagosMonograph.pdf (Accessed 17 th July 2018).

Owoeye, J. O. \& Adedeji, Y. (2015). Urban Land Acquisition for Sustainable Housing Delivery in Akure, Nigeria. International Journal of Developing Societies, 4(1), pp.10-20.

Peng, C.Y.J., Lee, K.L. \& Ingersoll, G.M. (2002). An Introduction to Logistic Regression Analysis and Reporting. The Journal of Educational Research, 96(1), pp.3-14.

Radin, M. J. (1982). Property and Personhood. Stanford Law Review, 34(5), pp.957-101.

Rakodi, C. (2007). Land for Housing in African Cities: Are Informal Delivery Systems Institutionally Robust and Pro-poor? In Land and Urban Policies for Poverty Reduction, M. Freire, L. Ricardo, D. Cira, B. Ferguson, C. Kessides, J. A. Mota, \& D. Motta (eds.). World Bank; Brasilia: Ipea, Washington, D.C. pp.227-243.

Rakodi, C. \& Leduka, C. R. (2004). Informal Land Delivery Processes and Access to Land for the Poor: A Comparative Study of Six African Cities. International Development Department, University of Birmingham, Birmingham. 
Schnably, S. J. (1993). Property and Pragmatism: A Critique of Radin's Theory of Property and Personhood. Stanford Law Review, pp.347407.

Smith, I. O. (2008). Sidelining Orthodoxy in Quest for Reality: Towards an Efficient Legal Regime of Land Tenure in Nigeria. University of Lagos Press, Lagos

Sigrid, V., McCoy, S. I., López-Peña, P., Muñoz, R., Larrieu, M. I. \& Celhay, P. (2017). How Accurate is Our Misinformation? A Randomised Comparison of Four Survey Interview Methods to Measure Risk Behaviour Among Young Adults in the Dominican Republic. Development Engineering, 2, pp.53-67.

Soludo, C. C. (2000). Comparative Institutional development: Lessons from rural land markets in Africa. Background Paper for the World Development Report, 2002. [Online]. Available at: https://pdfs.semanticscholar.org/c2c5/dd9bba96c4396b52f625ca889 23d89ec73d5.pdf (Accessed $1^{\text {st }}$ December 2017).

Staveren, I.V. \& Odebode, O. (2007). Gender Norms as Asymmetric Institutions: A Case Study of Yoruba Women in Nigeria. Journal of Economic Issues, 41(4), pp.903-925.

Toulmin, C. (2009). Securing Land and Property Rights in Sub-Saharan Africa: The Role of Local Institutions. Land Use Policy, 26(1), pp.1019.

United Nations. (2014). World Urbanisation Prospect. [Online]. Available at: https://esa.un.org/Unpd/Wup/Publications/Files/WUP2014Highlights.pdf (Accessed $1^{\text {st }}$ December 2017).

United Nations Human Settlements Programme (UN-HABITAT). (2014). Securing Land and Property Rights for All: Sustainable Land Management and Administration, High Level Forum on UN Global Geospatial Information Management, 22-24 October 2014. BeijingChina.

United Nations Human Settlements Programme (UN-HABITAT). (2015). Property Theory, Metaphors and the Continuum of Land Rights. [Online]. Available at:

http://www.ucalgary.ca/mikebarry/files/mikebarry/barry-2015-

property-theory-metaphors-and-the-continuum-of-land-rightspublished.pdf (Accessed 18 ${ }^{\text {th }}$ November 2017).

Varley, A. (1987). The Relationship Between Tenure Legalisation and Housing Improvements: Evidence from Mexico City, Development and change, 18(3), pp.463-481.

Wily, L. (2003). Governance and Land Relations: A Review of Decentralisation of Land Administration and Management in Africa. London: International Institute for Environment and Development

World Bank. (2014). LAGOS Metropolitan Development and Governance Project.[Online]. Available at: http://documents.worldbank.org/curated/en/872021468290442515/p df/ICR29680P071340IC0disclosed04040140.pdf (Accessed $9^{\text {th }}$ November 2017).

Yakub, A. A. (2014). An Appraisal of the Procedure for Direct Grant and Conversion of Statutory Right of Occupancy in Kaduna, Nigeria. Journal of African Studies and Development, 6(10), pp.179-189. 